\title{
Rain, dew, flourishing plants as images of monolatry and righteousness: The weather imagery and its meaning in Hosea
}

\begin{tabular}{|c|c|}
\hline $\begin{array}{l}\text { Author: } \\
\text { Szabolcs-Ferer }\end{array}$ & CZ Katón ${ }^{1,2}$ \\
\hline $\begin{array}{l}\text { Affiliations: } \\
{ }^{1} \text { Department } \\
\text { Testament Stu } \\
\text { Hebrew Script } \\
\text { of Theology a } \\
\text { University of P } \\
\text { Pretoria, Sout1 }\end{array}$ & $\begin{array}{l}\text { f Old } \\
\text { dies and } \\
\text { ures, Faculty } \\
\text { nd Religion, } \\
\text { retoria, } \\
\text { Africa }\end{array}$ \\
\hline $\begin{array}{l}{ }^{2} \text { Department o } \\
\text { Testament, Pro } \\
\text { Theological Ins } \\
\text { Cluj-Napoca, C } \\
\text { Romania }\end{array}$ & $\begin{array}{l}\text { f Old } \\
\text { testant } \\
\text { stitute of } \\
\text { luj-Napoca, }\end{array}$ \\
\hline $\begin{array}{l}\text { Corresponding } \\
\text { Szabolcs-Feren } \\
\text { katoszabolcs@ }\end{array}$ & $\begin{array}{l}\text { author: } \\
\text { lcz Kató, } \\
\text { yahoo.com }\end{array}$ \\
\hline $\begin{array}{l}\text { Dates: } \\
\text { Received: } 29 \mathrm{~N} \\
\text { Accepted: } 04 \mathrm{~J} \\
\text { Published: } 25\end{array}$ & $\begin{array}{l}\text { Mar. } 2021 \\
\text { une } 2021 \\
\text { Aug. } 2021\end{array}$ \\
\hline $\begin{array}{l}\text { How to cite th } \\
\text { Kató, S.-F., } 202 \\
\text { flourishing pla } \\
\text { of monolatry a } \\
\text { righteousness: } \\
\text { imagery and it } \\
\text { Hosea', HTS Te } \\
\text { Studies/ Theol } \\
77(4), \text { a6670. } \\
\text { org/10.4102/h }\end{array}$ & $\begin{array}{l}\text { is article: } \\
1 \text {, 'Rain, dew, } \\
\text { nts as images } \\
\text { and } \\
\text { The weather } \\
\text { s meaning in } \\
\text { ologiese } \\
\text { ogical Studies } \\
\text { tttps://doi. } \\
\text { tts.v77i4.6670 }\end{array}$ \\
\hline $\begin{array}{l}\text { Copyright: } \\
\text { (c) 2021. The A } \\
\text { Licensee: AOSI } \\
\text { is licensed und } \\
\text { Creative Comn } \\
\text { Attribution Lic }\end{array}$ & $\begin{array}{l}\text { uthors. } \\
\text { IS. This work } \\
\text { ler the } \\
\text { nons } \\
\text { ense. }\end{array}$ \\
\hline Read online: & \\
\hline 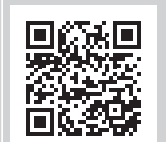 & $\begin{array}{l}\text { Scan this QR } \\
\text { code with your } \\
\text { smart phone or } \\
\text { mobile device } \\
\text { to read online. }\end{array}$ \\
\hline
\end{tabular}

Weather imagery plays a major role in Hosea. Hosea 2 recalls the image of an unfaithful wife; Hosea 4:2-3 describes the withering of the land; in $6: 3 ; 10: 12 ; 14: 6$, the several types of precipitation draw attention to the utterance of $\mathrm{YHWH}$ or the requested righteousness; in 9:10.13.16; 10:1; 13:5; 14:6.8, Israel is symbolised by different plants that blossom and wither, depending on their relation to Yhwh. In all of these instances, weather phenomena contribute to these images. In this article, I try to catalogue and evaluate the metaphors and concepts to look at how meteorological images convey theological and historical messages, and vice versa how historical events or sociological procedures demonstrate their consequences in nature, especially in the weather. It seems that weather imagery is used to describe the consequences of idolatry, injustice and false politics. These cause drought and famine in a concrete sense, but the withering of Israel figuratively, the last word of the book is a call for repentance that could ensure Israel's well-being once again. With these metaphors, Hosea explicitly delivers a plea for monolatry and righteousness, as well as for equality, in an implicit way. These pieces of evidence can provide a basis for further interpretation from the hermeneutical perspective of the notion called 'interconnectedness'.

Contribution: This article analyses the weather imagery of the Book of Hosea and contributes to a better understanding of the use of these metaphors in prophetic discourses.

Keywords: imagery; metaphor; Polemic; justice; Ba'al-cult.

\section{Introduction}

The Book of the Twelve is rather rich in natural imagery and different descriptions of weather phenomena. While sometimes these descriptions simply recall certain natural disasters or favourable weather conditions encountered in Israel (Joel 2:3; Am 4:7; Hag 1:11; Zech 10:1 etc.), in other cases they act as complex metaphors and allegories for historical events from their past. For example, in Joel 1 the famine and drought caused by locusts correlate with the Northern enemy's description (see Assis 2013:41; Levin 2014:220-222). Similarly, the foreign army is portrayed by the image of the locusts in Nahum 3:15 (Wolff 2004). In Nahum 2, the Assyrian Empire and its dynasty are represented by a lion family (Wessels 2014). From this perspective, the Book of Hosea features plenty of nature metaphors in which the weather imagery plays an extremely significant role. This article aims to enumerate and evaluate the metaphors and concepts present in the text, in order to reveal how meteorological images convey theological and historical messages and vice versa, and the consequences of certain historical events or sociological procedures, as manifested in nature, especially in the weather. It seems that weather imagery is used to highlight the consequences of idolatry, injustice and false politics. Recently, more and more attention has been paid to this phenomenon and it is being approached in several ways from the hermeneutical perspective of the notion called 'interconnectedness'. ${ }^{1}$ Although this article focuses primarily on the religious-social background of the formulation of prophetic message, its findings can lay ground for further such interpretations. For pragmatic reasons, I will present the motifs mainly in the order of their occurrence and whenever the same image reappears in the Book of Hosea, I will deal with it at the first instance.

\section{Hosea 2}

Hosea 2, taken as a whole, is a complex metaphor in itself, depicting the relationship of YHWH and his people. In Hosea 2:4, YHWH addresses the audience to plead for 'their mother' because

1.On this notion, see Habel (2000:44-46) and other volumes of the Earth Bible series. See also Kavusa (2020:1-13). For some insights of this reading in Hosea, see Wittenberg (2009:488-509); Kavusa (2016:481-501).

Note: Special Collection: Theology, Economy and Environment: Social, Cultural and Biotic Influences on Religious Communities, sub-edited by Jerry Pillay (University of Pretoria). 
'she has played the harlot' with her 'lovers' who are the 'Ba'als' (Hos 2:10.15.18). As a consequence of her behaviour, the adulterous wife is deprived of 'the bread, water, wool, flax, oil, and drink'. In this description, we can witness a love triangle and the intrigues beneath it. However, the identity of the people concerned beyond $\mathrm{YHWH}$ remains unclear. In the prophetic speech, the presence of YHWH is self-explanatory, therefore YHWH has to be the betrayed husband who is complaining about their mother's behaviour to his sons. But who is this mother, and who are her sons? Many try to correlate the wife simply with Israel, with the people of the land (Abma 1999:168-169; Andersen \& Freedman 1980:226; Davies 1993:32; Gruber 2017:108-109; Jeremias 1986:40-41; Macintosh 1997:40-41; Moughtin-Mumby 2008:257-263; Nwaoru 1999:14; Seifert 1996:114; Wolff 1990:39-40). In this case, Israel would be the unfaithful wife, who turns its back on YHWH and turns to other deities. As a result, the identity of the lovers/Ba'als is also determined: they should be other Canaanite deities (Abma 1999:113-114; Dearman 2010:124; Gruber 2017:119; Wolff 1990:48) or symbols of a compromised YHWH-religion, in which foreign elements had been integrated (Hubler 2020; Jeremias 1994). Like in the Deuteronomistic History, the Ba'als would be no more than a cypher for the other gods without regard to the Canaanite weather god, Ba'al-Hadad. Several foreign gods with different profiles can be subsumed under the name of Ba'al. However, this is not the only possibility.

The punishment of the wife is the withdrawal of food and clothes. In the case of a kingdom, this can only mean famine and drought. And if the lack of bread, water, and crops go hand in hand with agricultural disasters, then the wife cannot be Israel per se, but the fertile land (cf. Dearman 2010:59; Mays 1975:35), that became devastated by catastrophes caused by extreme weather. This interpretation is a slightly altered version of the previous one and in this case, the land and the people stand in an inseparable unity. The eco-theological reading of the text finds in this identification the basis for speaking in Hosea 2 about the Earth community (Braaten 2001:185-203).

Although these occurrences of the metaphor make a lot of sense and fit into the general theme of Hosea, several observations speak against such an interpretation. First of all, sons are also mentioned. If the mother is Israel, whom should they be? Other ethnicities? This is not at all likely. The rabbis have tried to solve this problem by dividing the addressees into two generations. The mother would be the sinful older generation, while the younger generation, the sons, have to plea with the ancestors for their unfaithfulness (cf. Macintosh 1997:40-41). However, the prophetic speech aims to bring an insight into the adulterous wife and tries to make it clear that YHWH is the provider of all agricultural goods (Hos 2:10). If Hosea 2 would be referring to the present generation, the main focus should be upon them and not upon the older generation. Therefore, another answer is to be sought.

Among others, Schmitt (1995), Keefe (2001:199), Kelle (2005:82-94), and Kató (2019:54-58) argue that the adulterous wife is in fact Israel's capital city, Samaria. This fits into the general picture of the prophecy, in which an addressed female entity generally stands for capital cities (cf. Fitzgerald 1972, 1975). ${ }^{2}$ Besides, identifying the wife with Samaria clarifies the rhetorical issue arisen by the sons, who ought to be part of Israel as well: they are the people of the land outside the capital. In that regard, they are sons of the women, as people depend on the political and sociological decisions made by the king and the aristocracy. Accordingly, Hosea 2 seems to reflect an issue between two social classes, aristocracy and the people of the land.

The cause of the conflict is the Ba'als. Kelle (2005:164-166, 199-200) sees another political designation here, as he identifies the lovers/Ba'als with the political allies of Israel during the Syro-Ephraimite war. This meaning appears clearly in Hosea 8:9, however, as we will see, a metaphor can be used differently in Hosea, depending on the context. Furthermore, in Hosea 2:15 these Ba'als have feasts, giving the term a ritual connotation that can hardly be explained by the conclusion of a suzerainty treaty, as Kelle (2005:264-265) proposes. Another hint of the religious use of the term stands in the fact that these Ba'als can overtake the function of YHWH in the people's daily lives. These observations added to the former ones, speak for the interpretation that the lovers / Ba'als are in fact gods.

If we look at the gifts (bread, water, linen, wool, oil, drink, corn, new wine) offered by these Ba'als, it will be clear that all these are agricultural products dependent on the weather and climate; in religious terms, depending on the benevolence of the storm god (Kató 2019:82-92). Since in Syro-Palestine the storm god is named Ba'al-Hadad, it is quite likely that Hosea 2 refers to this deity under the designation of the lovers and $\mathrm{Ba}^{\prime}$ als. ${ }^{3}$ The storm god with his local manifestations has repressed the official YHWH-cult.

These puzzle-pieces form the following picture: the aristocracy of Samaria (the woman) was unfaithful to YHWH and has been cheating on him with the storm god Ba'al (lovers). ${ }^{4}$ As a result, YHWH has punished the people with disasters caused by extreme weather, drought and famine. It is interesting, how religion and the described social reality interplay. At the time when Hosea 2 was written, whenever that was, the region in which the writer lived was probably suffering from agricultural disasters caused by rain shortage. In this situation, the prophet was eager to find an explanation for this economic catastrophe, and he made it look like the aristocracy of Samaria was responsible for the famine and water shortage. In the prophet's perspective, the religious injustice and idolatry have led to the punishment given by YHWH. Hosea 2 explains YHWH's punishment differently than Amos. Amos details the social abuse and injustice, while Hosea

2.See Isaiah 1:8; $50: 1-3 ; 52: 2 ; 54: 1-10 ;$ Jeremiah $2-3 ; 6: 3 ; 50,42 ; 51,33$; Lamentations 4:22; Ezekiel 16; 23; Micah 1:6-7; 4:10; Psalms 45,13; $137: 8$ etc.

3.The plural should be interpreted as local manifestation of the storm god, for which we have rich evidence in the extrabiblical sources (cf. Kató 2019:73-82).

4.There is a word play with name of the storm god Ba'al that means also 'husband'. Here the 'husband' is ironically addressed as 'lover' (Kató 2019:94). 
talks about religious transgressions. Although the land of the people seems to be faithful to $\mathrm{YHWH}_{1}{ }^{5}$ the capital city, Samaria, probably because of international relations and political marriages, compromised herself with the ba'alcult. Poor and rich are confronting each other, what is more, this conflict manifests itself in the religion as well, in the polemic against Ba'al.

\section{Hosea 4:1-3}

Hosea 4:1-3 was often read, especially from an ecotheological point of view (Kavusa 2016:481-501; Wittenberg 2009:488-509), and rightly so. In Hosea 4:3, the land dries up and withers with all the living on her surface. The reason for this general desolation is also mentioned in Hosea 4:2, where swearing, killing, stealing, and adultery, as well as bloodshed, are listed among committed crimes. In Hosea 4:1, they appear under the form of unfaithfulness, the lack of goodness and knowledge. Interestingly, the sins listed in Hosea 4:2 correspond verbatim with Exodus 20:13-15/ Deuteronomy 5:17-19 (the three commandments of the Decalogue). Even if the question, whether Hosea 4:2 falls back on an early form of the Ten Commandments (Gruber 2017:187-188; Macintosh 1997:130-131) or only on a common ethos that ultimately influenced the written commandments (Andersen \& Freedman 1980:337; Jeremias 1986:62) cannot be fully ruled out, it is obvious that the same ethical values, as well the written law-codes underlie, as in Hosea 4:2. The overthrow of the basic order leads to the jeopardy of the whole creation.

The world is represented in the three-tiered cosmos of the Ancient Near East, where land, sea, and sky denote the whole creation. The beasts of the field and the birds of the sky, and the fish of the sea resemble the creation-stories. Similar to the flood-narrative, Hosea 4:3 represents the undoing of the creation as a result of pervasive sin (Deroche 1981; Kavusa 2016:497-499; Landy 2011:54). However, in Hosea 4, YHWH does not destroy the land by employing a flood, but on the contrary, he provokes a drought (Gruber 2017:190). This becomes clear, as we notice the verbs אמל, which in several contexts bears the meaning 'to wither, to dry out', ${ }^{6}$ and which stays in certain contexts parallel to other verbs expressing the idea of drying out. ${ }^{7}$ However, this motif is not just a description of the devastation, of a specific event, but it also gets symbolic overtones. The transgressions shook the foundations of the world, which begins to die on all levels of life (Jeremias 1986:62-63). Nature reflects the social disorder and injustice, which manifests itself in weather phenomena. While in Hosea 2 religious issues have led to drought and famine, in the case of Hosea 4:3 it is a result of ethical abuses.

5. Hosea $2: 6$ breaks the line of thought, so it should be regarded as later addition to the text (Jeremias, 1986: 42; Rudnig-Zelt 2006:81; Vielhauer 2007:147; Yee 1987:108-110).

6.Isaiah 16:8; 24:4.7; 33:9 Joel 1:12 Nahum 1:4.

7.Isaiah 24:4; 33:9; Jeremiah 12:4; 23:10. Cf. Köhler and Baumgartner (2000): s.v. Many translations (KJV, NAS, NIB) assume here אבל I. 'to mourn' and return the meaning of the sentence with 'the land mourns'. However, the context speaks for the meaning 'dry up'.

\section{Hosea $6: 3 ; 10: 12 ; 14: 6$}

In the above-analysed passages, the drought was YHWH's instrument for punishment. So it is to be expected that the opposite, the undisturbed relation with YHWH, will be underlined by appropriate weather conditions, and that seems to be the case in Hosea 6:3. Here the utterance of God is described by terms of precipitation and dawn. The rising sun, the sunshine and the rain are all preconditions for abundant crops. Hosea 6:1-3 connects these phenomena with repentance and knowledge of God. Similarly, in Hosea 10:12 YHWH showers ${ }^{8}$ righteousness upon Israel when they 'sow according to righteousness' and 'reap in accordance with kindness'. Syro-Ephraimite war, in which YHWH sickens Israel for his transgressions. In Hosea 6:1-3 the people react to the sickness, they want to return to $\mathrm{YHWH}$ and they rely on his benevolence. The question is, whether this answer is the true voice of repentance (Gruber 2017:286-287; Landy 2011:79-80), or it is the form in which YHWH expected confession that never happened coming from the people (Macintosh 1997:216-219), or it is the expression of presumption: Israel is thinking of YHWH like a God bound in the rules of nature who will be merciful in any case (Jeremias 1986:86; Wolff 1990:148-151; cf. Dearman 2010:191). When seeking the answer to this question, it is striking that the reaction of $\mathrm{YHWH}$ is not the pure acceptance of these words, but a lamentation about the fickleness of Israel, whose loyalty disappears like the 'morning mist'. It seems, in this means, YHWH does not complain about the content of this confession, but rather about its temporariness. That means that the theological ideas expressed here are not rejected and can be a real confession of Israel. For our discussion, it is important, that the motifs of precipitation are connected to $\mathrm{YHWH}$, and the idea of abundant rain is a legitimate counterpart of the image of destruction described by drought and water shortness. These two opposite nature images reflect two opposite relations to YHWH. A similar image appears in Hosea 14:6, where YHWH, 'is like the dew to Israel'. Rain and dew are essential for agriculture in Israel. The land belongs to a subtropical climate region and the annual rainfall in Jerusalem is about $600 \mathrm{~mm}$ (Ben-Yoseph 1985:226). However, the city gets most of its rainfall on average in just 50 days (Ben-Yoseph 1985:227). Even if we have good reasons to take account of climate changes in the Late Bronze Age and beyond (Finkelstein \& Langgut 2014), and we are aware of the fact that the precipitation decreases in Israel with increasing distance from the Mediterranean Sea and from North to South (Knatsnelson 2007), the dew remains a determining factor for crop production that makes it possible to a certain extent even without irrigation (Ben-Yoseph 1985:229). Hence, dew, as well as rain, can symbolise abundant life and divine providence. While Hosea 4:3 talks about the slow languishing of the living beings, the dew in Hosea 14:6 stands for the daily and permanent love of God.

We can detect a very sharp contrast in the symbolism of the dew in Hosea 6:4 and 14:6. The former represents the 8.For the form oרֶ? I? see Rudolph (1971:132, 201), Schütte (2002). 
rhapsodic love and attachment of Israel; the latter stands for YHWH's constant care for his people. Without dew, agriculture, and as a result, the survival in the region is unimaginable. Though the dew evaporates once the sun is shining brightly, in these instances one can see, how the Book of Hosea engages twofold on the same motif when it comes to the dew, once for human incapability to remain faithful to YHWH and once for YHWH's unchangeable providence for a repentant Israel.

\section{Evaluation of the motifs}

As a very important background for these motifs, we can identify the religious ideas of Canaanite myths and epics. As we have said in Hosea 2, rain and the abundant harvest are gifts of the weather god. The drought and the dry weather are consequences of his death, for example in the Ba'al-Cycle (KTU 1.5 V 6-11 14-16). ${ }^{9}$ But Ba'al has three daughters of whom one called Tallay, 'dewy' (Smith \& Pitard 2009:119). This shows the connection between the dew and the weather god Ba'al. ${ }^{10}$ When Hosea speaks of the punishment and the gift from YHWH and illustrates them with terms of precipitation and water shortness, the book engages mythical concepts originating in the stories about the weather god. This applies to Hosea 4:2-3 as well. Although, in 6:3; 10:12; $14: 6$, these motifs go beyond the specific meaning of the detected mythologumena and have ethical overtones. Not only does Israel need to act righteously in order to have abundant rainfall, but the rain also becomes the rain of righteousness. In Hosea 6:3 and 14:6, YHWH not only comes to give rain and provide dew, but he is coming like rain and will be like the dew to Israel. In these motifs, we can see the afterlife of archaic mythical images. They appear demythicised with an ethical implication.

We can detect some differences between the use of the weather images in Hosea 2; 4:2-3 and Hosea 6:3; 10:12; 14:6. Hosea 2 appears to be a literal drought and is described by a large allegory of the unfaithful wife. This woman starves and thirsts to symbolise historical events. So mythical concepts and weather phenomena appear disguised in rich metaphors. The exact opposite happens in the instances listed later on, in which meteorological events become metaphorical and display righteousness or the providence of God. While in Hosea 2, the natural disaster is a consequence of inadequate religious behaviour, that of idolatry, in Hosea $6: 3 ; 10: 12$, the right social conduct appears in the form of weather phenomena. Hosea 4:2-3 can be placed between these two positions, in which the dry land is not merely the judgement of YHWH for the sins of the people, but at the same time it stands for the overturned social order. Here, nature mirrors the social problems and the specific climatic disasters become metaphors of the cosmic disorder. In this

9.Wyatt (2017) warns about interpreting the death and new reign of the Canaanite weather god Ba' in the Ugaritic Ba'-Cycle (KTU 1.1-1.6 +18) according to the pattern of the dying and rising gods. He corresponds the death and the new pattern of the dying and rising gods. He corresponds the death and the new enthronement of Ba'al with a funeral ritual (KTU 1.161), whereas the new king goes down to the tomb of the ancestors aiming to ensure the continuity between the
generations.

10.In the ANE, the dew was regarded as a form of precipitation (Wiggins 2003:87). part of Hosea, one can identify the interconnectedness of nature and community.

Even if we would have to prove it with further investigation, these observations attest to two different concepts of God. In Hosea 2 and from afar in Hosea 4:2-3, one can see YHWH acting like a powerful storm god (Kató 2019:92-100), while Hosea 6:3; 10:12 seems to guard justice and social order. This function in the Ancient Near East falls primarily within the competence of the sun god. Therefore, YHWH seems to take over the role of the sun god (Kató 2019:162-165), a very visible fact in the context of Hosea 6:3, and in Hosea 6:5, where the 'judgement of Yhwh goes forth like light'. ${ }^{11}$ Here the legal term does not make use of motifs of the weather god, but another natural phenomenon related to the sun god, namely the light. The connection between light and justice result from the fact that in daylight any offence is easier to detect. As Barmash (2020) aptly summarises:

The sun god's presence was manifested in sunlight, and presumably, nothing was hidden from the intense light (...). The sun god observed the activities of human beings in his journey sailing over the earth during the day. He was, therefore, in the appropriate position to judge human behaviour and supervise justice. (p. 34)

Thus the light can stay for justice per excellence and can be a sign of the divine order. This is the case of Hosea 6:5, where YHWH borrows the motifs of the sun god. Natural imagery can be a very good indicator of the development of divine concepts. The original mythic contents become more and more abstract by attracting ethical features, while the concrete natural images themselves turn into complex metaphors.

\section{Images for Israel}

In Hosea, favourable weather phenomena signals the undisturbed relationship with YHWH. Relating to this concept, Israel appears as a 'grape in the wilderness' (Hos 9:10); 'luxuriant vine' (Hos 10:1; 14:8); 'he blossoms like a lily' (14:6) and is 'like an olive tree' (14:8), 'he is planted in the meadow' (9:13). In these verses, floral metaphors describe the well-being of the people. On the other hand, the state of punishment is signalled by the counter images of the former metaphors. The grapevine (Israel) becomes unfruitful and 'the winepress does not feed them' (Hos 9:2); the fountain of blooming Israel will be dry (Hos 13:15); 'they reap storm' (Hos 8:7); the root of Israel 'is dried up' (Hos 9:16). When drought and rain are devices of YHWH's benevolence and judgement, so the flourishing and withering Israel simultaneously shows the two sides of the same coin.

Of course, the floral metaphors originate in the daily interaction with plants through agriculture and other economic sectors (Klingbeil 2013:251). However, the motifs have a long tradition behind them. A very likely link to the

11.In the sentence in question, another word division such as attested in the MS should be assumed. Instead of according to LXX, Vulg., Targ., Syr. Cf. BHQ. 
floral imagery can be identified within the so-called sacred tree (Klingbeil 2013:253), iconographically attested all around the Ancient Near East. Ever since the Middle Bronze Age, the symbol of the tree or the branch is used for growth and prosperity (Schroer \& Keel 2005:150). There are also indices of a cultic object in the form of a tree representing primarily a god, and as so, the sacred, blessing divine power (Giovino 2007:145-201). ${ }^{12}$ These topoi could have influenced the imagery of prophetic literature to engage floral metaphors for judgement and restoration.

Israel, referred to as YHWH's planted vineyard, appears in many prophetic books (Is 5:1-7; Jr 2:21; Ezk 15; 17:5-10; 19:10-14 etc.). In all of these instances, Israel does not fulfil the expectations of YHWH (the viticulturist). They either do not bear fruits or at least not appropriate ones. As a punishment, the winemaker uproots the vineyard and turns it into uncultivated land. This motif is traditionally associated with exile. The devastated, empty land as a consequence of mass deportation, is most visible in the curses of Deuteronomy 28 (cf. Lev 26), where the flourishing fields are signs of blessings and the decaying agricultural areas hint at breaking the covenant, which draws a curse upon Israel. In these texts, the floral imagery has covenantal overtones (Pantoja 2017:160-163). ${ }^{13}$

In the floral similes for Israel in Hosea, we can detect three types of plants playing a significant role: vine, olive, and fig tree. According to Hosea 9:10, YHWH finds Israel in the desert - like grapes and early figs. These motifs imply the image of the named trees. However, the mentioned desert is not a place of judgement like in $\mathrm{Num},{ }^{14}$ but on the contrary, it is an ideal period after the exodus, similarly to Deuteronomy $8 ; 32: 10$ or Jereremiah $2: 2 .{ }^{15}$

In the research, there is a debate on whether grapes can grow in the desert, and Hosea 9:10 attests to a miraculous finding of YHWH or it represents only a rarity, which can happen. Modern observations point to the possibility, that in extraordinary cases grapes can be grown in the Negev and are extremely sweet and delicious (Macintosh 1997:232). The same applies to early figs. Both metaphors express Israel's intrinsic value and the idea, that 'Yhwh was extremely pleased with Israel because of its intrinsic worth at the time'

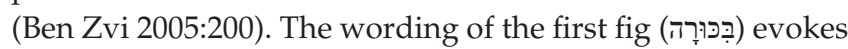

12. Such sacred trees have existed in Israel as well. They are often called as (Dt 16:21; Jdg 6:21 etc.), which could be a hint for a connection between the cultic origin of this object and the goddes with this name. Since Asherah is associated in the ANE with fertility, procreation and nursing, the sacred pole bearing her name the ANE with fertility, procreation and nursing, the sacred pole bearing her name
could have conveyed similar conceptions. On this topic see Kató (2019:248-250);
Korpel (2001:127-150); Smith (2004:54-55, 111-112, 114-116, 151, 153); Vriezen Korpel (2001:127-
(2001:61-67).

13.Pantoja (2017:45-50) tries to associate the idea of planting people with storm gods. Hovewer, the presented mythic material is very short and controversal in recent discussion.

14.Bach (1952:25-49) sees in Hosea 9:10 a competing tradition to the Exodusnarrative, that does not connect the desert with the Exodus. He has named it Fundtradition. However, in other instances Hosea clearly attest the desert linked to the exodus: Hosea $2: 16-17 ; 12: 10 ; 13: 4-5$, so the thesis is not convincing the exodus: Hosea 2:16-17;
(Cf. Jeremias 1986:121-122).

15.These positive associations of the desert seem to be older than of the Pentateuch (Römer 2011:78). Seifert (1996:110) on the contrary understands the desert here as a symbol for existential threat. further theological implications by resembling the first-born (כְּכ), another very common image for Israel (cf. Hos 11:1; Ex 4:2) (Ben Zvi 2005:200; Dearman 2010:251).

In the view of Hosea shortly after the ideal encounter of YHWH with the people in the desert, followed a period of unfaithfulness: the affairs at/with Ba'al-Peor (9:10), ${ }^{16}$ with Ba'al (13:1), or with other deities (10:1).

As a result, the aftermath of this idolatry is drying up the roots of Israel (9:16) and is subsiding his spring (13:15), in general, it is felt in the withering of the trees. The use of these images is similar to Hosea 2. The veneration of foreign gods, especially Ba'al, leads to the end of prosperity, which is expressed by images describing the consequences of drought and water shortness. However, while a historical event of a drought underlies Hosea 2, here the analysed images do not depict specific meteorological events, but rather war disasters. It is very likely, that primarily the Assyrian threat is envisaged here (Dearman 2010:257-258, Wolff 1990:211212). The expansion of Assyria and the fall of Samaria are described as the fruitlessness of Ephraim, on which rely the other images of the languishing. ${ }^{17}$ In Hosea 12:1, Assyria is represented by the east wind (Wolff 1990:297), and in Hosea $13: 5$, this east wind will dry up the springs, while in Hosea $8: 7$, Israel reaps a storm. The image used for Assyria is another meteorological phenomenon that fits easily in the metaphorical frame about Israel and its history.

The last word of Hosea is, however, not of judgement. In the case of repentance, the former state of prosperity can be restored. In the epilogue of the book (ch.14) it is announced that when the people quit seeking refuge with Assyria (false politics) and do not make themselves sinful in idolatry, they will blossom again like the lily and the olive tree (14:6-7), and YHWH will be for Israel like a luxuriant juniper (14:9). The lost paradise is regained (Eidevall 1996:213; Oestreich 1997:309). The motifs resemble topoi from the wisdom literature. Israel is once more associated with a 'tree planted by streams of water' (cf. Ps 1:3). 14:10 speaks of the wise and prudent, who understands the book. This ending stems clearly from a wisdom redactor (Macintosh 1995). So one should not omit to seek and identify the roots of the fruitbearing tree in wisdom, especially in the case of Hosea 14, (cf. Macintosh 1995; Oestreich 1997:260-270). Another topic approximating Hosea 14 to wisdom literature is the abstract idea of sacrificing the fruits of the lips. Similar ideas can be found in Proverbs 15:8; 21:3; Ecclesiastes 5:1. As a reward for this attitude, YHWH provides dew, and 'gives to the animals and birds what they need for survival, first of all, shelter and pleasant shade' (Oestreich 1997:309). It is striking that in this section several similes are used for YHWH (dew, juniper), as well as for Israel (lily, olive tree), but the implied associations remain almost the same.

16.Ba'al Peor can be understood as well as a location name or as a local manifestation of Ba'al at the place Peor (Cf. Macintosh 1997:360).

17. Hosea 9:16 contains a wordplay with the name of Ephraim and the thought of

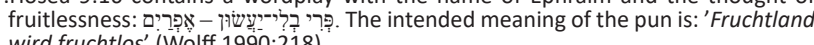
wird fruchtlos' (Wolff 1990:218). 


\section{Conclusion}

Hosea, similar to other books of the Twelve, uses natural imagery to convey a theological/religious message. Hosea 2 presents the image of an unfaithful wife, Hosea 4:2-3 describes the withering of the land; in $6: 3 ; 10: 12 ; 14: 6$ many types of precipitation signal the utterance of $\mathrm{YHWH}$ or requested righteousness are described; in 9:10.13.16; 10:1; 13:5; 14:6.8 Israel is symbolised by different plants that blossom and wither depending on their relationship with YHWH. In all of these instances, weather phenomena lay behind the images. We can also detect a tendency in the book, observed for instance in Hosea 2 and 4:2-3, where climatic events such as drought, water shortages seem to be phenomena taking place because of YHWH's punishment, in the later chapters rain and dew are linked to legal terms and ethical values like righteousness and justice, and they become more abstract. Similarly, the plant metaphors for Israel on the one hand display the well-being and prosperity of the land or even the opposite of this, on the other hand, they involve abstract values such as righteousness and the right veneration of YHWH. However, we can detect a common structure in the images as well. In each case, two claims can be found within: a religious and an ethical one.

In Hosea 2, Israel has to turn away from the Ba'als, from the local manifestation of the storm god. This call can be understood as the expression of monolatry. Likewise in Hosea 14:4, the people dissociate themselves from the idols, which means they only venerate YHWH. The worship of other gods, especially of Ba'al, polytheism calls the wrath of YHWH upon Israel. In order to illustrate these claims, the book uses different motifs, which evidently stay in connection with the storm gods. The abundant weather imagery demonstrates $\mathrm{YHWH}$ as being a storm god, who is more powerful than his opponent Ba'al. When Israel remains with $\mathrm{YHWH}$ he provides consistent rain and metaphorically the people can be like a luxurious vine, lily, olive, and fig tree.

In Hosea 4:2-3, the weather disasters are caused by ethical transgressions such as false swearing, killing, stealing and adultery, and by the lack of faithfulness and kindness. Hosea directly connects these social abuses with the experienced drought. The later chapters call Israel to sow according to righteousness to reap kindness. Presumably, the social disorder in which Hosea raises his word, can be traced back to social inequality, where the powerful oppress the weak. Very likely the aristocracy is envisaged as well in Hosea 2, where they are the mother of the land of the people, depicted as sons. Probably, the same social class is responsible for religious and ethical transgressions. Hosea calls for justice and equality.

As a subtopic, there appears to be false politics, whereas Israel seeks the grace of Assyria characterised as pursuing the east wind (12:1). As a result, the wind of YHWH dries up the land, so the people reap not righteousness but the storm (8:7). This critique fits most appropriately in the last phase of the Israelite Kingdom. Hosea explains the Assyrian occupation also as a result of missed politics. Of course, the main triggers of the political catastrophe are primarily the aristocracy.

In sum, weather imagery describes the consequences of idolatry, injustice, and false politics. These cause drought, famine in a concrete sense, therefore the withering of Israel in a figurative way. The last word of the book, although, is the call for repentance that can ensure the well-being of Israel again. Rain, water, food, flourishing plants are built up to masterful metaphors that want to attract Israel to the ideal state of the beginning again (cf. Hosea 2:17), to the only and righteous God. These findings can be lightly integrated and thought ahead in eco-theological interpretations of Hosea.

\section{Acknowledgements Competing interests}

The author declares that he has no financial or personal relationships that may have inappropriately influenced him in writing this article.

\section{Author's contributions}

Sz.F.K is the sole author of this article.

\section{Ethical considerations}

This article followed all ethical standards for research without direct contact with human or animal subjects.

\section{Funding information}

This research is part of the project 'Prophetic Studies' of Prof. Alphonso Groenewald in the Department of Old Testament and Hebrew Scriptures, Faculty of Theology and Religion, University of Pretoria.

\section{Data availability}

Data sharing is not applicable to this article as no new data were created or analysed in this study.

\section{Disclaimer}

The views and opinions expressed in this article are those of the author and do not necessarily reflect the official policy or position of any affiliated agency of the author.

\section{References}

Abma, R., 1999, Bonds of love: Methodic studies of prophetic texts with marriage imagery (Isaiah 50:1-3 and 54:1-10, Hosea 1-3, Jeremiah 2-3), Van Gorcum, Assen.

Andersen, F.I. \& Freedman, D.N., 1980, Hosea: A new translation with introduction and commentary, Doubleday, Garden City, NY.

Assis, E., 2013, The Book of Joel: A prophet between calamity and hope, Bloomsbury T \& T Clark, New York, NY.

Bach, R., 1952, 'Die Erwählung Israels in der Wüste', PhD thesis, Bonn.

Barmash, P., 2020, The Laws of Hammurabi. At the confluence of royal and scribal traditions, Oxford University Press, New York, NY. 
Ben-Yoseph, J., 1985, 'The climate in Eretz Isael during Biblical times', Hebrew Studies 26(2), 225-239.

Ben Zvi, E., 2005, Hosea, William B. Eerdmans Publishing Company, Grand Rapids, MI.

Braaten, L.J., 2001, 'Earth community in Hosea 2', in N. Habel (ed.), The earth story in the Psalms and the prophets, pp. 185-203, Sheffield Academic Press, Cleveland, $\mathrm{OH}$.

Davies, G.I., 1993, Hosea, JSOT Press, Sheffield.

Dearman, J.A., 2010, The book of Hosea, Eerdmans, Grand Rapids, MI.

Deroche, M., 1981, 'The reversal of creation in Hosea', Vetus Testamentum 31(4), 400-409. https://doi.org/10.1163/156853381X00316

Eidevall, G., 1996, Grapes in the desert: Metaphors, models, and themes in Hosea 4-14, Almqvist \& Wiksell International, Stockholm.

Finkelstein, I. \& Langgut, D., 2014, 'Dry climate in the middle Bronze I and its impact on settlement patterns in the levant and beyond: New Pollen evidence', Journal of Near Eastern Studies 73(2), 219-234. https://doi.org/10.1086/677300

Fitzgerald, A., 1972, 'The mythological background for the presentation of Jerusalem as a Queen and false worship as adultery in the OT', The Catholic Biblical Quarterly 34(4), 403-416.

Fitzgerald, A., 1975, 'Btwlt and Bt as titles for capital cities', The Catholic Biblical Quarterly 37(2), 167-183.

Giovino, M., 2007, The Assyrian aacred tree: A history of interpretations, Vandenhoeck \& Ruprecht, Göttingen.

Gruber, M.I., 2017, Hosea: A textual commentary, Bloomsbury International Clark, London.

Habel, N., 2000, Readings from the perspective of earth, Sheffield Academic Press, Cleveland, $\mathrm{OH}$.

Hubler, C., 2020, 'No longer will you call me my Ba'al: Hosea's polemic and the semantics of "Ba'al" in 8th century B.C.E. Israel', Journal for the study of the Old semantics of "Ba'al" in 8th century B.C.E. Israel', Journal for the study of
Testament 44(4), 610-623. https://doi.org/10.1177/0309089219862804

Jeremias, J., 1986, Der Prophet Hosea, Evangelische Verlagsanstalt, Berlin.

Jeremias, J., 1994, 'Der Begriff “Baal” im Hoseabuch und seine Wirkungsgeschichte', in W. Dietrich (ed.), Ein Gott allein?, Kolloquium der Schweizerischen Akademie der Geisteswissenschaften, pp. 441-462, Universitätsverlag, Freiburg.

Kató, S.-F., 2019, Jhwh: der Wettergott Hoseas?: der "ursprüngliche" Charakter Jhwhs ausgehend vom Hoseabuch, Vandenhoeck \& Ruprecht, Göttingen.

Kavusa, K.J., 2016, 'Social disorder and the trauma of the earth community: Reading Hosea 4:1-3 in light of today's crises', Old Testament Essays, N.S. 29(3), 481-501. https://doi.org/10.17159/2312-3621/2016/v29n3a8

Kavusa, K.J., 2020, Water and water-related phenomena in the Old Testament wisdom literature: An eco-theological exploration, T \& T Clark, London.

Keefe, A.A., 2001, 'Woman's body and the social body in Hosea', JSOTS 338, Sheffield Academic Press, Sheffield.

Kelle, B.E., 2005, Hosea 2: Metaphor and rhetoric in historical perspective, Brill, Leiden.

Klingbeil, M.G., 2013, 'Floral imagery', in M. Boda \& J.G. McConville (eds.), Dictionary of the Old Testament: Prophets, pp. 247-253, IVP Academic, Downers Grove, IL.

Knatsnelson, J., 2007, 'Rain', in F. Skolnik \& M. Berenbaum (eds.), Encyclopaedia Judaica 17, pp. 70-73, Thomson Gale, Detroit.

Köhler, L. \& Baumgartner, W., 2000, The Hebrew and Aramaic lexicon of the Old Testament, Brill, Leiden.

Korpel, M.C.A., 2001, 'Asherah outside Israel', in B. Becking, M. Dijkstm, M.C.A. Korpel \& K.J.H. Vriezen (eds.), Only one God? Monotheism in Ancient Israel and the Veneration of the Goddess Asherah, pp. 127-150, Sheffield Academic Press, London.

Landy, F., 2011, Hosea, Sheffield Phoenix Press, Sheffield.
Levin, C., 2014, 'Drought and locust plague in Joel 1-2', in E. Ben Zvi \& C. Levin (eds.) Thinking of water in the early second temple period, pp. 197-228, De Gruyter, Berlin.

Macintosh, A.A., 1995, 'Hosea and the wisdom tradition: Dependence and independence', in J. Day, R. Gordon \& H. Williamson (eds.), Wisdom in ancient Israel, pp. 124-132, Cambridge University Press, Cambridge.

Macintosh, A.A., 1997, A critical and exegetical commentary on Hosea, Clark, Edinburgh.

Mays, J.L., 1975, Hosea: A commentary, SCM-Press, London.

Moughtin-Mumby, S., 2008, Sexual and marital metaphors in Hosea, Jeremiah, Isaiah, and Ezekiel, Oxford University Press, Oxford.

Nwaoru, E.O., 1999, Imagery in the prophecy of Hosea, Harrassowitz, Wiesbaden.

Oestreich, B., 1997, 'Metaphors and similes for Yahweh in Hosea 14:2-9(1-8): A study of Hoseanic pictorial language', PhD thesis, Ann Arbor, MI.

Pantoja, J.M., 2017, The metaphor of the divine as planter of the people: Stinking grapes or pleasant planting?, Brill, Leiden.

Römer, T., 2011, 'Das deuteronomistische Geschichtswerk und die Wüstentraditionen der Hebräischen Bibel', in H.J. Stipp (ed.), Das deuteronomistische Geschichtswerk, pp. 55-88, Lang, Frankfurt am Main.

Rudnig-Zelt, S., 2006, Hoseastudien: redaktionskritische Untersuchungen zur Genese des Hoseabuches, Vandenhoeck \& Ruprecht, Göttingen.

Rudolph, W., 1971, Hosea, Evangelische Verlagsanstalt, Berlin.

Schroer, S. \& Keel, O., 2005, Die Ikonographie Palästinas, Israels und der Alte Orient. 1 Vom ausgehenden Mesolithikum bis zur Frühbronzezeit, Academic Press, Fribourg.

Schmitt, J. J., 1995, 'Yahweh's divorce in Hosea 2-Who is that woman?', Scandinavian Journal of the Old Testament 9, 119-132.

Schütte, W., 2002, 'Zwei Belege für einen qal-Stamm von jrh "benetzen, regnen lassen"', Zeitschrift für Althebraistik 15/16, 166-167.

Seifert, B., 1996, Metaphorisches Reden von Gott im Hoseabuch, Vandenhoeck \& Ruprecht, Göttingen.

Smith, M.S., 2004, Memoirs of God: History, memory, and the experience of the divine in ancient Israel, Fortress Press, Mineapolis, MN.

Smith, M.S. \& Pitard, W.T., 2009, The Ugaritic Baal cycle: Introduction with text, translation and commentary of KTU/CAT 1.3 - 1.4, Brill, Leiden.

Vielhauer, R., 2007, Das Werden des Buches Hosea: eine redaktionsgeschichtliche Untersuchung, De Gruyter, Berlin.

Vriezen, K.J.H, 2001, 'Aecheological traces of cult in Israel', in B. Becking, M. Dijkstm, M.C.A. Korpel \& K.J.H. Vriezen (eds.), Only one God? Monotheism in Ancient Israel and the Veneration of the Goddess Asherah, pp. 45-80, Sheffield Academic Press, London.

Wessels, W., 2014, 'Subversion of power: Exploring the lion metaphor in Nahum 2:12-14', Old Testament Essays, N.S. 27(2), 703-721.

Wiggins, S., 2003, 'Pidray, Tallay and Arsay in the Baal cycle', Journal of Northwest Semitic Languages 29(2), 83-101.

Wittenberg, G., 2009, 'Knowledge of God: The relevance of Hosea 4:1-3 for a theological response to climate change', Old Testament Essays, N.S. 22(2), 488-509. Wolff, H.W., 1990, Hosea, Neukirchener Verlag, Neukirchen-Vluyn.

Wolff, H.W., 2004, Joel und Amos, Neukirchener Verlag, Neukirchen-Vluyn.

Wyatt, N., 2017, 'The problem of "Dying and Rising" Gods: The case of Baal', Ugarit Forschungen 48, 819-845.

Yee, G.A., 1987, Composition and tradition in the Book of Hosea: A redaction critical investigation, Scholars Press, Atlanta, GA. 